\title{
ISOLASI DAN IDENTIFIKASI SENYAWA KIMIA \\ SERTA UJI AKTIVITAS ANTICANDIDAISIS \\ SERBUK BATANG SIRIH DUDUK (Piper sarmentosum Roxb. Ex Hunter)
}

\author{
Suwandri, Hartiwi Diastuti, Purwati \\ Program Studi Kimia, Jurusan MIPA, Fakultas Sains dan Teknik, UNSOED, Purwokerto
}

\begin{abstract}
Sirih duduk or Piper sarmentosum Roxb. ex Hunter have been long used the people in Indonesia for traditional medicine to cure various diseases. One of them was used to treat fungoid diseases. This research was aimed to examine the anticandidaisis activity from extract of $P$. sarmentosum bark, isolate and identify anticandidaisis compounds from $P$. sarmentosum bark. The isolation of bioactive compounds of $P$. sarmentosum bark was performed by extraction the powder of $P$. sarmentosum bark using methanol. The methanol extract was then fractionated using n-hexane, chloroform and ethylasetat. The fractions respectively was examined their activity against $C$. albican. The active extract was then fractionated performed by coloumn chromatography and was then separated performed by thin layer chromatography. Identification of bioactive compound was carry out using gas chromatography-mass spectrometry (GC-MS). The results show that chloroform, ethylasetat and methanol extracts of $P$. sarmentosum have more activities against $C$. albicans than miconazol. Bioactive compound from extract of $P$. sarmentosum bark was bis(2-ethylhexyl)phtalat.
\end{abstract}

Key word: Piper sarmentosum, bioactivity test, C. albicans, phtalat

\section{PENDAHULUAN}

Sejak munculnya peradaban di muka bumi ini, tumbuhan telah digunakan manusia untuk berbagai keperluan. Selain sebagai bahan pangan, sandang, papan dan bahan bakar, tumbuhan juga menghasilkan bahanbahan kimia yang telah digunakan sebagai bahan obat-obatan, insektisida, wangi-wangian, zat warna, dan kosmetik.

Indonesia merupakan negara tropis yang kaya akan keanekaragaman jenis tumbuhan. Di wilayah hutan tropis Indonesia terdapat sekitar 30.000 spesies tumbuhan. Berdasarkan inventarisasi dan identifikasi yang dilakukan oleh Heyne, (1987) 1000 spesies di antaranya dinyatakan sebagai tumbuhan yang dapat digunakan sebagai obat. Tetapi hanya sekitar 350 spesies tumbuhan yang benarbenar telah digunakan sebagai bahan baku obat oleh masyarakat dan industri jamu dan obat Indonesia (Muhlisah, 2000). Hal ini mengisyaratkan masih terbukanya peluang usaha penggalian dan pemanfaatan tumbuhan obat untuk kesehatan dan kesejahteraan masyarakat.

Salah satu tumbuhan obat Indonesia adalah sirih duduk atau Piper sarmentosum Roxb. ex Hunter yang sekarang belum banyak diteliti. Tumbuhan ini termasuk famili Piperaceae. Di beberapa bagian negara di Asia, tumbuhan ini telah dikenal sebagai tumbuhan berkhasiat obat. Di antaranya air rebusan tumbuhan ini digunakan untuk mengobati sakit gigi, asma, batuk, nyeri tulang, dan infeksi jamur serta untuk membersihkan vagina (Kasahara, 1995). Pada mulanya alasan penggunaan tumbuhan ini hanya berdasarkan pengalaman secara turuntemurun. Setelah dilakukan penelitian, dilaporkan bahwa ekstrak tumbuhan 
Piper sarmentosum memiliki aktivitas antimikroba (Masuda, 1991), efek hipoglycemic (Peungvicha, 1998), menghilangkan nyeri otot (Ridtidtid, 1998), dan antimalaria (Rahman, 1999).

Kandungan kimia metabolit sekunder sirih duduk sampai saat ini belum banyak diketahui. Pada tahun 1991, Masuda melaporkan bahwa senyawa antimikroba yang ditemukan dalam daun sirih duduk adalah dari golongan fenil propanoid. Senyawa tersebut berhasil diisolasi dari ekstrak benzena dan diuji bioaktivitasnya terhadap bakteri Escherichia coli dan Bacillus subtilis. Dengan demikan tidak tertutup kemungkinan ditemukannya senyawa lain yang juga memiliki aktivitas antimikroba terutama terhadap jamur Candida albicans pada batang dari tumbuhan ini.

\section{METODE PENELITIAN Bahan}

Bahan yang digunakan untuk penelitian adalah daun sirih duduk (Piper sarmentosum Roxb. Ex hunter) yang diambil di Desa Purwosari Kecamatan Baturraden Purwokerto. Bahan kimia yang digunakan adalah : pelarut organik seperti metanol, etil asetat, kloroform, dan $n$-heksana; silika gel $60 \mathrm{GF}_{254}$, medium pertumbuhan jamur, yaitu bactoagar, bacto-tryptone, bacto-yeast extract; jamur $C$. albicans, akuades, $\mathrm{NaCl}$, kertas saring, dan paper dish.

\section{Peralatan Penelitian}

Peralatan yang diperlukan dalam penelitian ini meliputi : seperangkat alat soxkletasi, rotaryevaporator, hot plate, neraca analitis, autoklaf, inkubator, pipet mikro, kawat ose dan peralatan gelas yang biasa digunakan di laboratorium kimia. GC-MS merk Shimadzu QP 2010s.

\section{Prosedur Percobaan}

\section{Isolasi dan identifikasi senyawa kimia serbuk daun sirih duduk}

Batang sirih duduk segar yang telah dibersihkan dari kotoran yang menempel, dikeringkan di tempat terbuka kemudian digiling halus. Serbuk kering yang diperoleh $(375,00 \mathrm{~g})$ diperkolasi atau dimaserasi dengan metanol selama dua hari (48 jam) pada suhu kamar. Pelarut kemudian diuapkan dengan rotary evaporator. Ekstrak metanol selanjutnya diekstraksi berturut-turut dengan $n$-heksana, kloroform dan etil asetat. Masing-masing ekstrak yang terlarut dalam $n$-heksana, kloroform, etil asetat dan metanol diuapkan pelarutnya. Ekstrak yang telah kering selanjutnya diuji aktivitasnya terhadap C. albicans. Ekstrak dari pelarut tertentu yang memiliki aktivitas terhadap $C$. albicans digunakan untuk tahap isolasi dan identifikasi senyawa kimianya.

Ekstrak dari pelarut yang memiliki aktivitas terhadap $C$. albicans dikolom kromatografi yang dielusi dengan sistem gradien kepolaran menggunakan eluen $n$-heksana, etil asetat, kloroform dan metanol atau dengan campuran keempat eluen tersebut. Senyawa murni dari hasil kromatografi, kemudian diidentifikasi dengan menggunakan spektrofotometer GC-MS.

\section{Uji bioaktivitas anticandidaisis}

Sebelum dilakukan pengujian bioaktivitas anticandidaisis, maka perlu dibuat larutan medium pertumbuhan mikroba. Medium yang digunakan adalah medium LB (Luria-Bertani) cair dan medium LB (Luria-Bertani) padat. Untuk uji aktivitas ekstrak yang digunakan adalah $10 \quad \mu \mathrm{L}$ dengan konsentrasi $1 \mathrm{mg} / \mathrm{mL}$.

Medium LB cair dibuat dengan melarutkan 1,0 g bacto-tryptone, 0,5 g bacto-yeast extract dan $1,0 \mathrm{~g} \mathrm{NaCl}$ ke 
dalam $100 \mathrm{~mL}$ akuades. Larutan kemudian disterilisasi dengan autoklaf pada suhu $250^{\circ} \mathrm{F}$ dan tekanan 15 psi selama 30 menit. Untuk pembuatan medium LB padat hampir sama dengan pembuatan LB cair, hanya saja perlu penambahan bacto-agar sebanyak 1,5\% $(\mathrm{b} / \mathrm{v})$.

Pengujian bioaktivitas dilakukan dengan metode difusi agar menggunakan paper dish. Metode ini paling banyak digunakan dalam pengujian aktivitas antibiotik. Pada pengujian ini semua bahan dan alat yang akan digunakan harus dalam keadaan steril, agar hasil yang diperoleh tidak terkontaminasi oleh mikroba yang lain.

Prosedur pengujian aktivitas adalah sebagai berikut : jamur $C$. albicans ditumbuhkan dalam medium LB cair 48 jam pada suhu $37^{\circ} \mathrm{C}$. Kondisi tersebut adalah kondisi optimum untuk pertumbuhan jamur. Sebanyak $200 \mu \mathrm{L}$ kultur mikroba cair disebarkan secara merata di atas medium LB padat. Selanjutnya paper dish berukuran $6 \mathrm{~mm}$ diletakkan di atas medium padat tersebut dan pada paper dish diteteskan $10 \mu \mathrm{L}$ ekstrak tumbuhan. Masing-masing kultur diinkubasi selama 48 jam pada suhu $37^{\circ} \mathrm{C}$. Setiap ekstrak diulang sebanyak 2 kali. Kemudian diukur daerah hambat (daerah bening di sekitar paper dish) dari masing-masing mikroba untuk setiap fraksi ekstrak tumbuhan. Untuk kontrol negatif digunakan pelarut dari fraksi ekstrak tumbuhan. Adanya daerah bening di sekitar paper dish menunjukkan bahwa senyawa tersebut memiliki aktivitas anticandidaisis.

\section{HASIL DAN PEMBAHASAN}

Ekstraksi serbuk batang sirih duduk dengan cara perkolasi menggunakan pelarut metanol menghasilkan ekstrak kering sebanyak 18,93 g. Serbuk batang sirih yang digunakan sebanyak 375,00 g. Dengan demikian persentase hasil ekstraksi adalah sebesar 5,0\% (b/b). Ekstrak metanol yang diperoleh selanjutnya difraksinasi dengan menggunakan pelarut berturut-turut $n$-heksana, kloroform, etilasetat, dan residu metanol. Ekstrak yang dihasilkan dari fraksinasi tersebut masing-masing sebesar 4,94;3,34; 1,25 dan $7,40 \mathrm{~g}$.

Uji aktivitas anticandidaisis ekstrak $n$-heksana, kloroform, etilasetat serta metanol dilakukan dengan metode difusi agar menggunakan kertas cakram. Dalam metode ini, ekstrak yang akan diuji diteteskan pada kertas cakram yang diletakkan di atas medium padat yang telah diinokulasi dengan bakteri tertentu. Ekstrak yang memiliki aktivitas anticandidaisis akan berdifusi pada medium dan akan mempengaruhi pertumbuhan bakteri. Pengamatan dilakukan dengan melihat daerah bening di sekitar kertas cakram. Dalam penelitian ini sebagai kontrol positif digunakan mikonazol. Hasil uji anticandidaisis ekstrak n-heksana, kloroform, etilasetat serta metanol terhadap jamur $C$. albicans dapat ditampilkan pada Tabel 1. 
Molekul, Vol. 2. No. 2. Nopember, 2007 : 53-58

Tabel 1. Hasil uji anticandidaisis ekstrak sirih duduk terhadap C. Albicans

\begin{tabular}{clccc}
\hline \multirow{2}{*}{ No } & \multirow{2}{*}{ Ekstrak } & \multicolumn{3}{c}{ Diameter hambat (mm) } \\
\cline { 3 - 5 } & & I & II & Rata-rata \\
\hline 1. & n-Heksana & 14 & 15 & 14,5 \\
2. & Kloroform & 17 & 18 & 17,5 \\
3. & Etilasetat & 17,5 & 20 & 18,7 \\
4. & Metanol & 16,5 & 18 & 17,3 \\
5. & Miconazol & 16 & 16 & 16 \\
\hline
\end{tabular}

Pada Tabel 1 dapat dilihat bahwa ekstrak kloroform, etilasetat dan metanol memiliki aktivitas lebih besar dibandingkan mikonazol sebagai kontrol positif, hanya ekstrak n-heksana saja yang memiliki aktivitas lebih kecil dibandingkan mikonazol. Selanjutnya ekstrak kloroform digunakan untuk tahap berikutnya, yaitu isolasi dan identifikasi senyawa kimia.

Ekstrak kloroform dicampur dengan silika gel, digerus hingga terbentuk butiran halus. Ekstrak yang telah berbentuk butiran halus ini dimasukkan ke dalam kolom kromatografi yang telah diisi dengan silika $60 \mathrm{GF}_{254}$ dan eluen $n$-heksana. Selanjutnya dilakukan elusi sistem gradien kepolaran. Pelarut yang digunakan adalah n-heksana dan kloroform serta campuran keduanya.

Fraksi-fraksi yang didapat dari kromatografi kolom yang mengandung komponen yang sama disatukan dan dikeringkan. Hal ini dilakukan setelah diperiksa dengan kromatografi lapis tipis (KLT). Hasil KLT diamati dengan larutan penampak bercak asam sulfat $10 \%$ dalam etanol dan dilihat dengan lampu uv $256 \mathrm{~nm}$.
Berdasarkan hasil kromatografi kolom ini didapat 6 fraksi, yaitu : I (83,0 mg), II (12 $\mathrm{mg})$, III (62,0 mg), IV (2,0 mg ), V (52,0 $\mathrm{mg})$ dan VI (221,0 mg). Fraksi-fraksi tersebut diuji aktivitas anticandidaisisnya. Hasil uji anticandidaisis fraksi-fraksi dapat dilihat pada Tabel 2 di bawah ini.

Tabel 2. Hasil uji anticandidaisis fraksifraksi ekstrak kloroform terhadap $C$. albicans

\begin{tabular}{|c|c|c|c|}
\hline \multirow[b]{2}{*}{ Fraksi } & \multicolumn{3}{|c|}{ Diameter hambat (mm) } \\
\hline & I & II & $\begin{array}{l}\text { Rata- } \\
\text { rata }\end{array}$ \\
\hline I & 8 & 8 & 8 \\
\hline II & 9 & 10 & 9,5 \\
\hline III & 11 & 12 & 11,5 \\
\hline IV & 11 & 11 & 11 \\
\hline V & 12 & 13 & 12,5 \\
\hline VI & 14 & 14 & 14 \\
\hline
\end{tabular}


Pada Tabel 2 dapat dilihat bahwa fraksi VI memiliki aktivitas paling tinggi dibandingkan fraksi lainnya. Selanjutnya fraksi VI ini digunakan untuk tahap berikutnya, yaitu identifikasi komponen senyawa kimianya dengan menggunakan GC-MS.

Berdasarkan pengukuran dengan GC-MS diketahui bahwa ternyata fraksi VI mengandung 7 komponen (jumlah pita pada spektrum GC-MS) dengan komponen 4 sebagai komponen utamanya. Persentase luas area komponen 4 sebesar 92\% dengan waktu retensi 22,588 menit.

Analisis spektrum MS komponen 4 diketahui mempunyai berat molekul 390 dengan puncak dasar pada m/z 149 . Puncak pada m/z 279 berasal dari $\mathrm{C}_{24} \mathrm{H}_{38} \mathrm{O}_{4}{ }^{+}$yang disebabkan oleh lepasnya $\mathrm{C}_{8} \mathrm{H}_{15}{ }^{\bullet}$ dari ion molekul diikuti dengan pelepasan $\mathrm{C}_{8} \mathrm{H}_{16}$ membentuk $\mathrm{C}_{8} \mathrm{H}_{7} \mathrm{O}_{4}{ }^{+}$yang tampak pada $\mathrm{m} / \mathrm{z} 167$. Ion ini kemudian melepaskan $\mathrm{H}_{2} \mathrm{O}$ membentuk puncak dasar pada m/z 149, yang merupakan puncak khas senyawa ftalat (Sastrohamidjojo, 1988) yang terjadi melalui pemecahan 2 ester yang melibatkan penataan ulang 2 atom $\mathrm{H}$ (penataan ulang McLafferty) disertai pelepasan $\mathrm{H}_{2} \mathrm{O}$ (Silverstein, dkk, 1991). Fragmentasi ini juga terjadi pada ikatan $\mathrm{C}-\mathrm{O}$ ester, di mana ion molekul melepaskan $\mathrm{C}_{6} \mathrm{H}_{25} \mathrm{O}_{4}{ }^{\bullet}$ membentuk $\mathrm{C}_{8} \mathrm{H}_{17}{ }^{+}$ yang tampak pada $\mathrm{m} / \mathrm{z} 113$, kemudian melepaskan $\mathrm{C}_{2} \mathrm{H}_{6}$ membentuk $\mathrm{C}_{6} \mathrm{H}_{11}{ }^{+}$ yang tampak pada $\mathrm{m} / \mathrm{z} 83$. Puncak pada $\mathrm{m} / \mathrm{z} 57$ berasal dari $\mathrm{C}_{4} \mathrm{H}_{9}{ }^{+}$yang disebabkan oleh lepasnya $\mathrm{C}_{2} \mathrm{H}_{2}$ dari $\mathrm{C}_{6} \mathrm{H}_{11}$ yang diikuti dengan pelepasan $\mathrm{CH}_{2}$ membentuk $\mathrm{C}_{3} \mathrm{H}_{7}{ }^{+}$yang terlihat pada $\mathrm{m} / \mathrm{z}$ 43. Pola fragmentasi komponen 4 dapat dilihat pada Gambar 1.

Berdasarkan perbandingan spektrum MS komponen 4 dengan spektrum MS senyawa bis(2-etilheksil) ftalat, ternyata kedua spektrum memiliki pola fragmentasi yang sama. Dengan demikian komponen 4 diduga merupakan senyawa bis(2-etilheksil) ftalat $\left(\mathrm{C}_{24} \mathrm{H}_{38} \mathrm{O}_{4}\right)$ dengan struktur seperti pada Gambar 2.

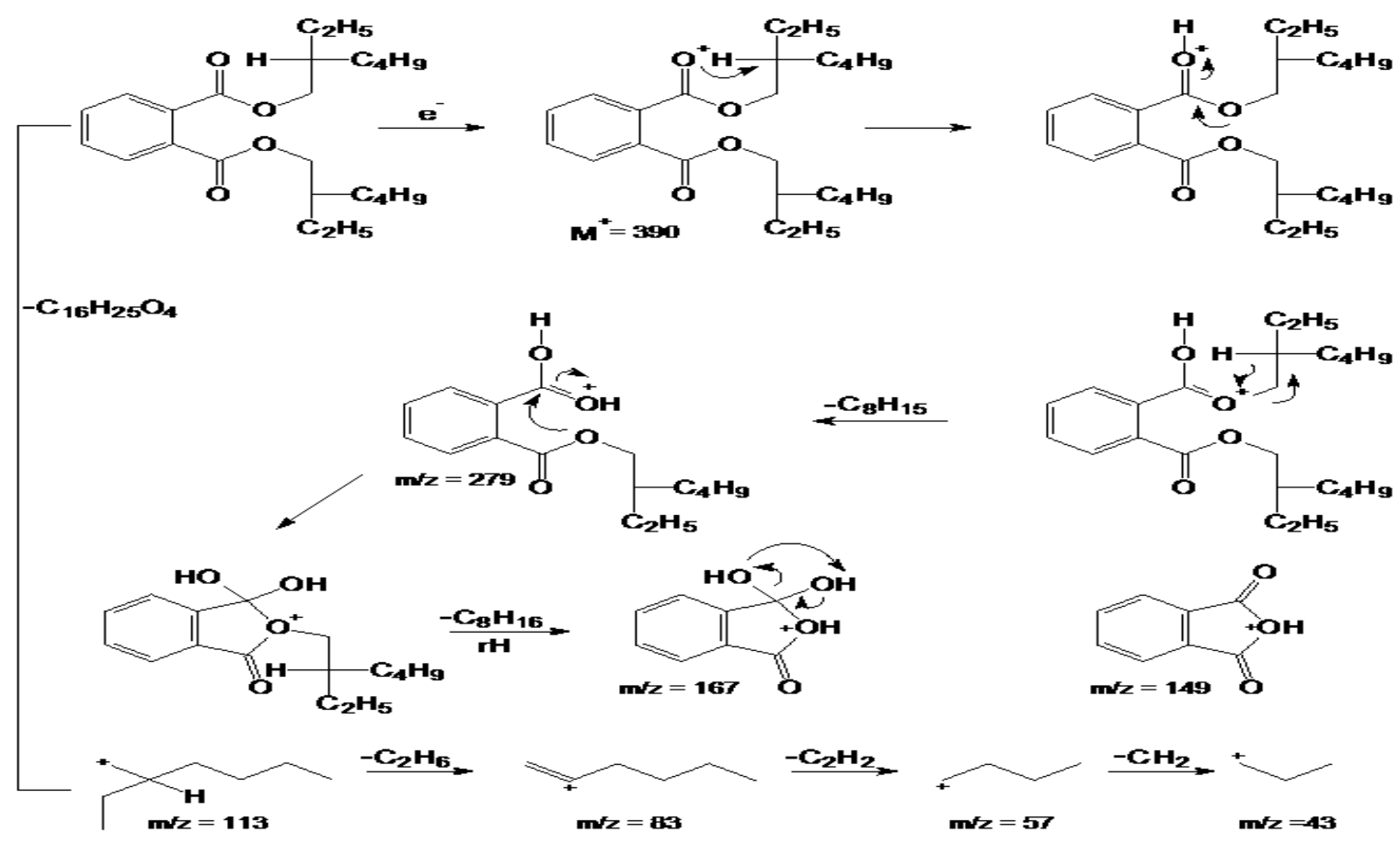

Gambar 1. Pola fragmentasi komponen 4 


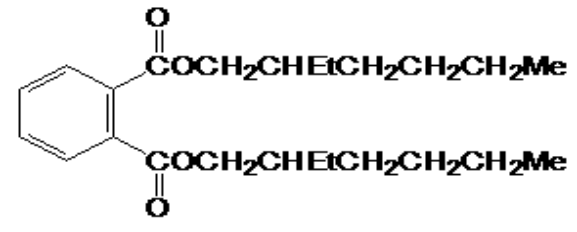

Gambar 5. Senyawa bis(2-etilheksil)ftalat

\section{DAFTAR PUSTAKA}

Heyne, K. 1987. Tumbuhan Berguna Indonesia. Jilid II. Badan Litbang Kehutanan. Jakarta. 20-23.

Kasahara. 1995. Medical Herb Index in Indonesia. Edisi-2. Esai Indonesia. Jakarta. 20-23.

Masuda, T. 1991. Antimicrobial Phenylpropanoid from Piper sarmentosum. Phytochemistry. 30 (10). 3227-3228.

Muhlisah, F. 2000. Tanaman Obat Keluarga. Penebar Swadaya. Jakarta.1-3.

Peungvicha. P. 1998. Hypoglycemic Effect of The Water Extract of Piper sarmentosum in Rats. J. of Ethnopharmacology. 60. 27-32.

Rahman, A.N. 1999. Antimalaria Activity of Extract of Malaysia Medical Plant. J. of Ethnopharmacology. 64. 249-259.

\section{KESIMPULAN}

Hasil isolasi dan identifikasi senyawa bioaktif anticandidaisis dari ekstrak batang sirih duduk diperoleh adalah senyawa bis(2-etilheksil)ftalat. Hasil uji bioaktivitas anticandidaisis menunjukkan bahwa ekstrak kloroform, etilasetat dan metanol dari batang sirih duduk memiliki aktivitas terhadap $C$. albicans lebih besar dibandingkan mikonazol.

Ridtidtid, W. 1998. Neuromoscular Blocking Activity of Metanol Ekstract of Piper sarmentosum Leaves in Rat Phrenic NerveHemidiaphragm Prepadation. J. of Ethnopharmacology. 61. 135-142.

Sastrohamidjojo, H. 1988. Interpretasi Spektra Massa. GMU Press. Yogyakarta.

Silverstein, R.M., Bassler, G.C. and Morril, T.C. 1991. Spectrometric Identification of Organic Compounds. Fifth edition. John Wiley and Sons Inc. New York. 